УДК 351:338.2

DOI: https://doi.org/10.32689/2618-0065-2018-1/1-7-13

Андріснко Микола Васильович доктор наук 3 державного управління, доцент, начальник науково-дослідного центру заходів цивільного захисту, Українського науково-дослідного інституту цивільного захисту, м. Київ, вул. Рибальська, 18, 01011, Україна тел.: (044)-280-18-01, e-mail.: andnv@ukr.net

ORCID: 0000-0002-9222-4831

\title{
КЛЮЧОВА РОЛЬ ЕКОНОМІЧНОГО СУВЕРЕНІТЕТУ В КОНТЕКСТІ ЗАБЕЗПЕЧЕННЯ БЕЗПЕКИ ДЕРЖАВИ В ЕКОНОМІЧНІЙ СФЕРІ
}

Анотація. В умовах незалежності України, становлення ії як демократичної держави, прагнення вступити до євроатлантичних структур, бути повноправним членом Свропейського Союзу загроза різноманітних небезпек суттєво збільшується, саме тому проблема забезпечення національної безпеки $\epsilon$ актуальною, а іiі розв'язання пов'язане $з$ необхідністю мати єдину систему знань про національну безпеку, володіти ефективною методикою вивчення іiї структурних складників, а також методологічної бази для аналізу, оцінки і прогнозування, прийняття рішень у галузі управління національною економікою. Концепція економічної безпеки України базується на нормах Конституції України i визначає основні засади державної політики, спрямованої на захист національних інтересів та гарантування безпеки особи, суспільства, держави від внутрішніх та зовнішніх загроз.

Відзначено, що економічна безпека $є$ багатофакторною категорією, яка характеризує здатність національної економіки до розширеного само відтворення, до подальшого її розвитку, задовольняє потреби власного населення держави на визначеному рівні, протистоїть дії різноманітних чинників, внутрішніх i зовнішніх. Тобто, це характеристика, яка захищає будь-який об'єкт від впливу внутрішніх і зовнішніх факторів та загроз.

Доведено, що в сучасних умовах економічна безпека країни набуває особливого значення, оскільки дає орієнтири для прийняття основних соціальноекономічних рішень. Мова йде насамперед про самостійний економічний розвиток, враховуючи наявність національних державних інтересів і підтримку державного суверенітету.

Конституційні норми стосуються різних видів безпеки, серед яких важливе місце займає саме економічна безпека, оскільки з нею тісно пов'язані стабільний і динамічний розвиток національної економіки, іï ефективність і 
конкурентоспроможність на внутрішньому i світовому ринках.У статті виокремлено та проаналізовано характерні риси економічного суверенітету, продемонстрований взаємозв’язок економічного суверенітету й економічної безпеки, виявлені фактори, які впливають на суверенність України в умовах глобалізації, показаний вплив глобальних економічних тенденцій на економічний суверенітет та запропоновані напрямки зменшення загроз економічному суверенітету у контексті забезпечення економічної безпеки.

Ключові слова: економічний суверенітет, економічна безпека, глобалізацій ні процеси, стратегічний розвиток, національний інтерес.

Andrienko Nikolay Vasilievich Doctor of Sciences in Public Administration, assistant professor, Head of Research Center of Civil Protection Measures, Ukrainian Research Institute of Civil Protection, Kyiv, st. Rybalska, 18, 01011, Ukraine tel .: (044) -280-18-01, e-mail: andnv@ukr.net

ORCID: 0000-0002-9222-4831

\section{KEY ROLE OF ECONOMIC SOVEREIGNITY IN THE CONTEXT OF PROVIDING THE SECURITY OF THE STATE IN ECONOMIC SECTOR}

Annotation. In the conditions of Ukraine's independence, the formation of its as a democratic state, the desire to join the Euro-Atlantic structures, to be a full member of the European Union, the threat of various dangers is significantly increasing, which is why the problem of ensuring national security is relevant, and its solution is related to the need to have a unified system knowledge of national security, to have an effective method of studying its structural components, as well as a methodological basis for analysis, evaluation and forecasting, decision-making in the field of Ukrainian national economy. The concept of Ukraine's economic security is based on the norms of the Constitution of Ukraine and defines the main principles of state policy aimed at protecting national interests and guaranteeing the safety of individuals, societies and states from internal and external threats.

It is noted that economic security is a multifactorial category that characterizes the ability of the national economy to expand its reproduction, to further its development, satisfies the needs of its own population of the state at a certain level, opposes the actions of various factors, internal and external. That is, it is a characteristic that protects any object from the influence of internal and external factors and threats.

It is proved that in today's conditions the country's economic security becomes very important as it provides guidance for the adoption of basic socio-economic decisions. It is primarily about independent economic development, taking into account the existence of national state interests and support of state sovereignty. 
The constitutional rules relate to various types of security, among which the most important place is economic security, since it is closely linked to the stable and dynamic development of the national economy, its efficiency and competitiveness in the domestic and world markets. The article features and analyzes the characteristic features of economic sovereignty, demonstrated the relationship of economic sovereignty and economic security, the factors that influence the sovereignty of Ukraine in the conditions of globalization are revealed, the influence of g obalnyh economic trends on economic sovereignty and offered help reduce the threat to economic sovereignty in the context of economic security.

Key words: economic sovereignty, economic security, globalization processes, strategic development, national interest.

Постановка проблеми. Сучасний етап світового розвитку характеризується процесами інтеграції економічного, політичного, культурного життя і надає нові можливості розвитку людської цивілізації. У широкий вжиток увійшов термін «глобалізація» як характеристика формування єдиного планетарного суспільства. Глобалізація є об’єктивним процесом, який несе в собі як переваги, так і недоліки, і все більше розмежовує країни за рівнем економічного розвитку. У зв'язку з цим основною задачею у сфері державного управління, в тому числі й України $\epsilon$ перетворення існуючого фундаментального суспільного консенсусу в сфері безпеки у довгострокову стратегію, яка б сприяла забезпеченню економічної безпеки та економічного суверенітету.

Аналіз останніх досліджень $\boldsymbol{i}$ публікацій. Питання дослідження економічного суверенітету та економічної безпеки в умовах взаємопроникнення та взаємозалежності національних економік висвітлені у працях вітчизняних і зарубіжних учених, таких як Абалкін А., Білоус В., Геєць В., Губський Б, Мунтіян В. та інші. Невирішеною частиною загальної проблеми вважаємо саме забезпечення не лише економічної безпеки держави, а й економічного суверенітету та підвищення його значення для держави.

Формулювання цілей статmі. Метою дослідження $\epsilon$ забезпечення економічної безпеки та економічного суверенітету в умовах глобалізації.

Виклад основного матеріалу дослідження. На сьогоднішній день поняття «суверенітет» $\epsilon$ нечітким, незважаючи на його застосування усіма країнами світу. Економічний суверенітет пов'язаний з державним суверенітетом, і розглядається як верховенство держави на власній території. Так, Британська біржа (LSE) дає таке визначення: економічний суверенітет — це влада або національні уряди, які приймають рішення незалежні від рішень, які сформульовані іншими урядами [1]. В економічній енциклопедії «економічний суверенітет» розглядається як 
економічна незалежність держави, іiї право самостійно вирішувати внутрішні і зовнішні економічні питання, без втручання в них будь-якої іншої держави [2].

Економічний суверенітет безпосередньо пов’язаний з економічною безпекою країни, навіть зазначимо, що національна безпека $\epsilon$ складовою національного суверенітету. Розвиток соціально-економічної думки доводить, що проблема безпеки сприймалася завжди як найважливіша в будь-якій соціальній структурі, починаючи з індивідууму. Безпека для будь-якої країни посідає особливе місце в діяльності країни. Існує величезна кількість визначень категорії «економічна безпека».

Сьогодні існує безліч визначень «економічної безпеки». Як зазначається в Концепції Національної безпеки України, економічна безпека являє собою такий стан національної економіки, який дає можливість:

- гарантувати економічний розвиток держави на підставі досягнень науковотехнічного прогресу;

- зберігати або швидко оновлювати виробництво в умовах припинення зовнішніх поставок або надзвичайних ситуацій внутрішнього характеру;

- забезпечувати стійке функціонування своєї кредитно-грошової системи і задоволення потреб суспільства за несприятливих внутрішніх і зовнішніх умов.

Економічна безпека держави в сучасних умовах світового розвитку має обов’язково підтримувати національну ідею, національні інтереси, що є спільною ознакою всіх розвинених країн, і виступає рушійною силою і найсильнішим фактором мобілізації суспільства, основою консенсусу, засобом реалізації його потенціалу. Одночасно зазначимо, що національні інтереси $є$ перешкодою на шляху до крайнощів розвитку суспільства: 3 одного боку - до державного соціалізму, а з іншого - до ринкового фундаменталізму, характерного для периферії світового господарства. Крім того, національна економічна безпека сама $\epsilon$ національним економічним інтересом, тому що забезпечення безпеки особи, суспільства і держави $є$ неодмінною умовою виживання країни, без чого стає неможливим досягнення цілей іншого порядку.

Крім підтримки національних інтересів, забезпечення економічної безпеки виступає гарантом державної незалежності суверенної України і умовою іiі прогресивного економічного розвитку і зростання добробуту громадян.

Економічний суверенітет надає уряду можливість приймати рішення, враховуючи свої національні інтереси, й робити власний вибір незалежний від урядів інших країн світу. Але, варто відзначити, що в умовах глобалізації, коли економіки країн характеризуються такими властивостями, як взаємопроникнення, взаємозалежність, економічний суверенітет і економічна незалежність може залежати від багатьох факторів, включаючи економіку розвинених країн світу 
(особливо країн Великої сімки, Росії, Китаю). Економічна міцність країн визначається знанням країни, виробництва, фінансів і безпеки.

За останні два десятиріччя майже усі країни прискорили темпи економічного розвитку. Країни намагаються скористатися перевагами процесу глобалізації, прискорити свій економічний розвиток, створити нові ринкові можливості тощо. Країни інтегрують свою економіку у світовий ринок і створюють такі економічні імпульси, які призведуть до економічного зростання, і до світового лідерства.

В ситуації боротьби за світові економічні ніші одні країни можуть нав'язувати іншим не тільки свою конфігурацію господарських відносин i взаємодій, а й потрібну їм модель світового господарського устрою, яка суттєво впливатиме на політичний устрій інших держав, підриватиме їхню економічну самостійність, позбавляти їх такого статусу, який асоціюється 3 поняттям «економічний суверенітет» [3]. Такого роду тактика дає найкращий результат стосовно держав, які не мають вагомого економічного потенціалу, належної економічної самодостатності та конкурентоспроможності, а відтак і фактичної рівності у міжнародних відносинах.

Отже, для будь-якої країни відкрита економіка несе загрозу економічному суверенітету, що призводить до його послабленні, та безпеці, що має прояв у прийнятті рішень, які не відповідають національним інтересам. Послаблення економічного суверенітету та збільшення рівня небезпеки відбуваються через загрози привілеїв над господарською діяльністю, природними ресурсами країни, національним багатством.

Найчастіше економічний суверенітет та економічна безпека має прояв у стосунках із зовнішнім середовищем. Сьогодні варто виокремити економічно сильні держави, потужні інтеграційні угруповування (наприклад, СС) та окремі транснаціональні корпорації, чиї дії позначені загрозою національним економічним суверенітетам.

Прямих загроз економічному суверенітету України зовнішнє середовище не має, але разом з тим утвердження Україною своєї суверенності в умовах впливу на неї чинників, породжених глобалізацією, супроводжується виникненням ряду проблем, найпомітнішими з яких є такі [3]:

- входження української держави у сферу міжнародно-правових відносин, встановлених під контролем і насамперед в інтересах розвинутих держав з усталеними демократіями;

- приєднання України до міжнародних пактів зобов'язувального i рекомендаційного характеру, що стосуються прав людини, за обставин, коли у ній зберігається ряд рудиментів тоталітарної політичної культури, робить ії 
постійним об’єктом критики з боку міжнародних інституцій і дає підстави для втручання в її внутрішне життя;

- взяття Україною зобов'язань щодо захисту національних меншин використовується деякими їхніми історичними Батьківщинами для морального і політичного тиску на українську владу;

- технологічне відставання України від рівня світових лідерів; необхідність виходу на світовий ринок з продукцією, конкурентоспроможність якої залежить від імпорту енергетичних та інших ресурсів, веде до того, що, приєднуючись до різних міжнародних організацій глобального і регіонального рівня, вона не може забезпечити собі там рівноправне становище, що створює умови для політичного та економічного тиску на неї з боку потужніших держав;

- збільшення вірогідності безпосереднього впливу на державну владу з боку транснаціональних корпорацій, чия активність в Україні має ознаки зростання і в активізації діяльності яких в Україні зацікавлена сама держава.

Загалом економічний суверенітет знаходиться під впливом глобальних економічних тенденцій, й збільшення кількості різних агентів (ТНК, міжнародних організацій тощо), що беззаперечно обмежують в певному ступеню суверенітет кожної окремої країни, особливо слаборозвиненої. Іноді ТНК характеризуються як найбільша загроза національним суверенітетам, які фактично керують урядами і всією міжнародною системою. Такі оцінки зумовлені наявною питомою вагою транснаціональних корпорацій у світовій економіці.

Висновки. Таким чином, економічний суверенітет та забезпечення економічної безпеки для України є основою забезпечення стратегічного розвитку на основі національних інтересів. Забезпечення економічної безпеки є гарантом державної незалежності України, умовою ії прогресивного економічного розвитку і зростання добробуту громадян.

Основними напрямами зменшення загроз економічному суверенітету у контексті забезпечення економічної безпеки мають бути:

- безперервне економічне зростання держави, збільшення темпів зростання ВВП, прискорення темпів зростання промислового виробництва;

- приборкання інфляції, зменшення рівня безробіття, підвищення стійкого рівня розвитку економіки;

- зростання добробуту населення;

- скорочення дефіциту бюджету та державного боргу, підтримка стійкості національної валюти тощо.

Перспективним для подальших наукових досліджень $є$ вплив економічно розвинених країн, провідних міжнародних організацій та ТНК на економічний 
суверенітет держави, враховуючи сучасні глобалізаційні тенденції світової економіки.

\section{Лimepamypa:}

1. London South East. URL : http://www.lse.co.uk.

2. Економічна енциклопедія. URL : http://slovopedia.org.ua

3. Національний суверенітет України в умовах глобалізації: Національна доповідь. Київ : Парламентське вид-во, 2011. 112 с.

\section{References:}

1. Site of London South East. www.lse.co.uk. Retrieved from http://www.lse.co.uk [in English].

2. Sait Slovopedia [Site of Slovopedia]. slovopedia.org.ua. Retrieved from http://slovopedia.org.ua [in Ukrainian].

3. Natsionalnyi suverenitet Ukrainy $\mathrm{v}$ umovakh hlobalizatsii: Natsionalna dopovid [National Sovereignty of Ukraine in the Conditions of Globalization: National Report]. (2011). Kyiv: Parlamentske vyd-vo [in Ukrainian]. 